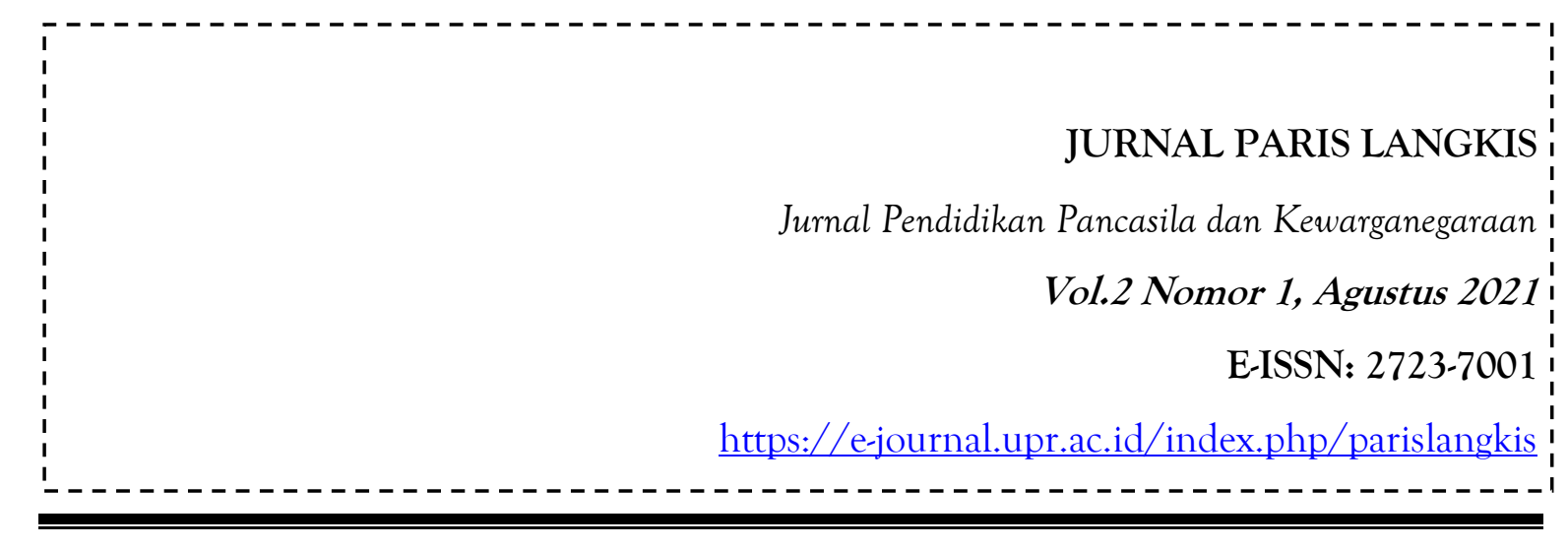

\title{
KORELASI MOTIVASI DAN DISIPLIN BELAJAR SISWA DENGAN HASIL BELAJAR SIMULASI DAN KOMUNIKASI DIGITAL
}

\author{
Menrisal \\ Universitas Putra Indonesia YPTK Padang, Indonesia \\ E-mail:menrisal@upiyptk.ac.id
}

\begin{abstract}
Abstrak
Penelitian ini bertujuan untuk mengetahui korelasi motivasi belajar dan disiplin belajar siswa dengan hasil belajar pada siswa. Jenis penelitian ini adalah kuantitatif dengan menggunakan metode penelitian korelasional. Penelitian ini dilakukan di SMKN 6 Padang. Populasi dalam penelitian ini yaitu seluruh siswa kelas X di SMKN 6 Padang. Teknik pengambilan sampel yang digunakan adalah proporsional random sampling. Yang terpilih menjadi sampel dalam penelitian ini berjumlah 200 orang siswa. Berdasarkan hasil penelitian, diperoleh korelasi motivasi belajar (X1) terhadap hasil belajar sebesar 0,8097, selanjutnya diperoleh korelasi disiplin belajar (X2) terhadap hasil belajar sebesar $0,3658\left(_{R \text { tabel }}=0,138\right)$ dengan $t_{\text {hitung }}=19,419$ untuk variabel $X_{1}$ dan $Y$ dan $t_{\text {hitung }}=5,5310$ variabel $X_{2}$ dan Y $\left(t_{\text {hitung }} t_{\text {tabel }}\right)$, Maka dapat ditarik kesimpulan bahwa korelasi dikatakan positif dan signifikan.
\end{abstract}

Kata Kunci: motivasi belajar; disiplin belajar; hasil belajar

\section{A. PENDAHULUAN}

Pendidikan adalah usaha sadar dan terencana untuk mewujudkan suasana belajar dan proses pembelajaran agar siswa secara aktif mengembangkan potensi dirinya untuk memiliki kekuatan spiritual keagamaan, pengendalian diri, kepribadian, kecerdasan, akhlak mulia serta keterampilan yang diperlukan dirinya, masyarakat, bangsa dan negara. Pendidikan memiliki peranan yang sangat penting untuk menjamin perkembangan dan kelangsungan kehidupan bangsa karena pendidikan merupakan suatu proses dalam usaha membentuk manusia yang cerdas dan terampil, mewujudkan sumber daya manusia (SDM) yang berkualitas dan kreatif serta mampu bersaing dalam menghadapi tantangan dan kemajuan ilmu pengetahuan serta tekhnologi.

Demi tercapainya tujuan pendidikan, maka diperlukan kerjasama yang baik antara guru dan siswa dalam mencapai tujuan pendidikan tersebut bersama-sama. Terdapat faktor

\section{Paris Langkis}

Vol.2 Nomor 1, Agustus 2021 
internal dan eksternal yang mempengaruhi keberhasilan proses belajar mengajar yang berujung kepada hasil belajar siswa. Faktor internalnya antara lain: disiplin belajar, motivasi belajar, kecerdasan emosional, minat belajar siswa, dan beberapa faktor pendukung lainnya. Sedangkan faktor eksternalnya dapat berupa lingkungan sekolah, lingkungan keluarga, keterampilan mengajar guru, serta faktor-faktor lainnya (Ahmadi, 2010). Pada penelitian ini akan dibahas faktor internal berupa disiplin belajar dan motivasi belajar.

Menurut (Affifudin, 2008) disiplin belajar merupakan suatu posisi kecenderungan suatu sikap mental untuk mematuhi aturan, tata tertib dan sekaligus mengendalikan dan menyesuaikan diri terhadap aturan-aturan yang berasal dari luar sekalipun yang mengekang dan menunjukkan kesadaran akan tanggung jawab terhadap tugas dan kewajiban. Selanjutnya disiplin belajar dapat dimaknai sebagai suatu proses dan latihan belajar yang bersangkut paut dengan pertumbuhan dan perkembangan, seseorang dapat dikatakan berhasil mempelajari, jika mengikuti dengan sendirinya proses dikatakan berhasil mempelajari, jika mengikuti dengan sendirinya proses disiplin tersebut (Irianto, 1988). Faktor berikutnya yang dapat mempengaruhi hasil belajar adalah motivasi belajar.

Motivasi belajar merupakan keseluruhan daya penggerak dalam diri siswa yang menimbulkan kegiatan belajar, yang menjamin kelangsungan dari kegiatan belajar dan memberikan arah pada kegiatan belajar, sehingga tujuan yang dikehendaki oleh subyek belajar itu dapat tercapai (Sudijono, 2011). Selanjutnya menurut (Asmara, 2009 ) motivasi belajar dapat timbul karena faktor intrinsik, berupa hasrat dan keinginan berhasil dan dorongan kebutuhan belajar, harapan akan cita-cita. Sedangkan faktor ekstrinsiknya adalah adanya penghargaan, lingkungan belajar yang kondusif, dan kegiatan belajar yang menarik. Keberhasilan proses belajar mengajar siswa akan terlihat melalui hasil belajar yang diperoleh siswa. Dimana hasil belajar merupakan hasil usaha bekerja atau belajar yang menunjukan ukuran kecakapan yang dicapai dalam bentuk nilai (Bima, 2016). Hasil belajar dapat juga dimaknai sebagai hasil usaha belajar yang berupa nilai-nilai sebagai ukuran kecakapan dari usaha belajar yang telah dicapai seseorang, prestasi belajar ditunjukan dengan jumlah nilai raport atau test nilai sumatif (Wijaya, 2001). Selanjutnya hasil belajar diterjemahkan juga sebagai hasil yang dicapai seseorang dalam pengusasaan pengetahuan dan keterampilan yang dikembangkan dalam pelajaran, lazimnya ditunjukkan dengan tes angka nilai yang diberikan oleh guru (Mudijono, 2006).

Berdasarkan observasi yang peneliti lakukan di SMKN 6 Padang, maka diperoleh informasi bahwa masih banyak ditemukan siswa yang datang terlambat ke sekolah, para siswa yang setelah jam pelajaran dimulai siswa tidak segera masuk ke kelas, pada saat jam pelajaran kosong siswa sering gaduh dan meninggalkan kelas serta berkeliaran di kantin sekolah. Kemudian masih banyak siswa yang mencontek pada saat ulangan dan rata-rata siswa mengerjakan PR di sekolah. Selain itu, peneliti juga menemukan beberapa masalah lainnya yang berkaitan dengan motivasi belajar siswa. Dimana peneliti menemukan beberapa informasi diantaranya yaitu: motivasi belajar siswa yang masih rendah, hal ini terlihat dari cara siswa mengikuti proses belajar mengajar, dimana para siswa tidak memperhatikan apa yang dijelaskan guru di depan kelas. Hal tersebut disebabkan oleh kurang menariknya cara penyampaian materi oleh guru bidang studi yang bersangkutan. Selanjutnya peneliti menemukan hasil belajar simulasi dan komunikasi digital siswa kelas X di SMK Negeri 6 masih tergolong rendah. Hal ini terlihat dari banyaknya siswa yang tidak

\section{Paris Langkis}

Vol.2 Nomor 1, Agustus 2021 
berhasil mencapai standar ketuntasan minimum (KKM) yang telah ditetapkan. Untuk lebih jelasnya dapat dilihat pada tabel berikut ini:

Tabel 1. Data observasi awal

\begin{tabular}{lllll}
\hline \multirow{2}{*}{ No } & Kelas & \multicolumn{2}{l}{ Nilai } & Jumlah Siswa \\
\cline { 3 - 5 } & & $\mathbf{2 7 5}$ & $\mathbf{2 7 5}$ & \\
\hline 1 & X TB 1 & 12 & 18 & 30 \\
\hline 2 & X TB 2 & 11 & 19 & 30 \\
\hline 3 & X PHT 1 & 11 & 21 & 32 \\
\hline 4 & X PHT 2 & 10 & 22 & 32 \\
\hline 5 & X PHT 3 & 14 & 18 & 32 \\
\hline 6 & X JB 1 & 13 & 18 & 31 \\
\hline 7 & X JB 2 & 12 & 18 & 30 \\
\hline 8 & X JB 3 & 10 & 21 & 31 \\
\hline 9 & X PTS 1 & 11 & 19 & 30 \\
\hline 10 & X PTS 2 & 10 & 20 & 30 \\
\hline 11 & X TKJ & 9 & 19 & 28 \\
\hline 12 & X TKK & 14 & 19 & 33 \\
\hline 13 & X TKR & 13 & 19 & 32 \\
\hline Total & 150 & 251 & 401
\end{tabular}

Berdasarkan tabel $1 \mathrm{di}$ atas dapat diketahui bahwa siswa yang memiliki nilai di bawah standar ketuntasan minimum yaitu di bawah 75 ada sebanyak 150 orang siswa, sedangkan yang berada di atas 75 adalah 251 orang siswa. Untuk mengetahui kebenaran fakta dan fenomena yang peneliti temukan di lapangan, maka peneliti mengangkat judul penelitian yaitu "Korelasi Motivasi Belajar dan Disiplin Belajar Siswa Dengan Hasil Belajar Pada Siswa Kelas X di SMK Negeri 6 Padang.

\section{B. TINJAUAN LITERATUR}

Hasil belajar ialah sebagai terjadinya perubahan tingkah laku pada diri seseorang yang dapat di amati dan di ukur bentuk pengetahuan, sikap dan keterampilan. Perubahan tersebut dapat diartikan sebagai terjadinya peningkatan dan pengembangan yang lebih baik sebelumnya yang tidak tahu menjadi tahu (Djamarah, 2008). Selanjutnya menurut (Engkoswara, 2010) Hasil belajar ialah hasil yang dicapai dalam bentuk angka-angka atau skor setelah diberikan tes hasil belajar pada setiap akhir pembelajaran. Nilai yang diperoleh siswa menjadi acuan untuk melihat penguasaan siswa dalam menerima materi pelajaran.

Hasil belajar adalah angka yang diperoleh siswa yang telah berhasil menuntaskan konsep-konsep mata pelajaran sesuai dengan kriteria ketuntasan minimal (KKM) yang ditetapkan sesuai dengan kurikulum yang berlaku (Popy (KONTRIBUSI LINGKUNGAN BELAJAR DAN SARANA PRASARANA TERHADAP HASIL BELAJAR SISWA MATA PELAJARAN TIK (Studi Kasus Kelas XI IPS SMA PGRI 1 Padang), 2020). Begitu juga hasil belajar dapat diartikan sebagai "perubahan tingkah laku yang tetap sebagai hasil proses pembelajaran” (Wallen, 2008) . Hasil belajar dapat diklasifikasikan menjadi tiga ranah, yaitu ranah kognitif, afektif, dan psikomotorik. Prinsip yang mendasari penilaian hasil belajar yaitu untuk memberi harapan bagi siswa dan guru untuk dapat meningkatkan kualitas pembelajaran.Kualitas dalam arti siswa menjadi pembelajar yang efektif dan guru

\section{Paris Langkis}

Vol.2 Nomor 1, Agustus 2021 
menjadi motivator yang baik. Dalam kaitan dengan itu, guru dan pembelajar dapat menjadikan informasi hasil penilaian sebagai dasar dalam menentukan langkah-langkah pemecahan masalah, sehingga mereka dapat memperbaiki dan meningkatkan belajarnya (Hamdani, 2006).

Setiap proses belajar yang dilaksanakan oleh peserta didik akan menghasilkan hasil belajar. Di dalam proses pembelajaran, guru sebagai pengajar sekaligus pendidik memegang peranan dan tanggung jawab yang besar dalam rangka membantu meningkatkan keberhasilan peserta didik dipengaruhi oleh kualitas pengajaran dan faktor intern dari siswa itu sendiri. Setiap mengikuti proses pembelajaran di sekolah sudah pasti setiap peserta didik mengharapkan mendapatkan hasil belajar yang baik, sebab hasil belajar yang baik dapat membantu peserta didik dalam mencapai tujuannya. Hasil belajar yang baik hanya dicapai melalui proses belajar yang baik pula. Jika proses belajar tidak optimal sangat sulit diharapkan terjadinya hasil belajar yang baik.

Motivasi belajar adalah keseluruhan daya penggerak dalam diri siswa yang menimbulkan kegiatan belajar, yang menjamin kelangsungan dari kegiatan belajar dan memberikan arah pada kegiatan belajar, sehingga tujuan yang dikehendaki oleh subyek belajar itu dapat tercapai (Hamalik, 2008). Selanjutnya menurut (JUWITA, Penelitian Hubungan Gaya Belajar dengan Hasil Belajar pada Mata Pelajaran Simulasi dan Komunikasi Digital, 2019) motivasi belajar dapat timbul karena faktor intrinsik, berupa hasrat dan keinginan berhasil dan dorongan kebutuhan belajar, harapan akan cita-cita. Sedangkan faktor ekstrinsiknya adalah adanya penghargaan, lingkungan belajar yang kondusif, dan kegiatan belajar yang menarik.Motivasi belajar adalah keseluruhan daya penggerak baik dari dalam diri maupun dari luar siswa (dengan menciptakan serangkaian usaha untuk menyediakan kondisi-kondisi tertentu) yang menjamin kelangsungan dan memberikan arah pada kegiatan belajar, sehingga tujuan yang dikehendaki oleh subjek belajar itu dapat tercapai. Motivasi belajar dapat dilihat dari karakter tingkah laku siswa yang menyangkut minat, ketajaman perhatian, konsentrasi dan tekun mencapai tujuan. Cotoh dan bentuk bentuk motivasi belajar diantaranya adalah pujian, memberi angka, hadiah, gerakan tubuh, memberi tugas, memberi ulangan, mengetahui hasil, hukuman (Mahendra, 2008).

Sejalan dengan pendapat (Menrisal, 2018) yang menyatakan bahwa motivasi belajar didefenisikan sebagai suatu kemampuan internal yang terbentuk secara alami yang dapat ditingkatkan atau dipelihara melalui kegiatan yang memberikan dukungan, memberikan kesempatan untuk memilih kegiatan, memberikan tanggung jawab untuk mengontrol proses belajar, dan memberikan tugas-tugas belajar yang bermanfaat dan sesuai dengan kebutuhan pribadi.

Disiplin belajar adalah melakukan kegiatan atau aktivitas rutin seperti belajar dengan sungguh-sungguh penuh dengan ketekunan dan cara belajarnya yang baik membawa hasil yang memuaskan. Menurut (Moenir, 1995) "Disiplin belajar adalah kemampuan seseorang untuk secara teratur belajar dan tidak melakukan sesuatu yang dapat merugikan tujuan akhir dari proses belajarnya”. Disiplin belajar tidak hanya berupa kemampuan untuk belajar secara teratur, tetapi juga didukung dengan tidak melakukan sesuatu yang melanggar peraturan yang dapat merugikan tujuan akhir dari belajar. Disiplin belajar meliputi disiplin belajar di rumah dan di sekolah.

\section{Paris Langkis}

Vol.2 Nomor 1, Agustus 2021 


\section{METODOLOGI}

Jenis penelitian ini adalah kuantitatif korelasional. Metode penelitian kuantitatif adalah metode yang digunakan untuk meneliti populasi atau sampel tertentu, pengumpulan data menggunakan instrument penelitian, analisis data bersifat statistik, dengan tujuan untuk menguji hipotesis yang diajukan (Mujiono, 2006). Sedangkan penelitian korelasional adalah suatu penelitian untuk mengetahui hubungan dan tingkat hubungan antara dua variabel atau lebih tanpa ada upaya untuk mempengaruhi variabel tersebut sehingga tidak terdapat manipulasi variabel (Mukhlis, 2016).

Penelitian ini bertujuan melihat korelasi persepsi siswa tentang keterampilan mengajar guru dengan hasil belajar Simulasi dan Komunikasi Digital siswa kelas X di SMKN 6 Padang. Populasi adalah wilayah generalisasi yang terdiri atas objek/subjek yang mempunyai kualitas dan karakteristik tertentu yang ditetapkan oleh peneliti untuk dipelajari dan kemudian ditarik kesimpulannya. Populasi dalam penelitian ini diambil dari seluruh siswa kelas X di SMKN 6 Padang yang berjumlah 401 siswa. Sumber data berasal dari data primer dan data sekunder. Teknik analisis data yaitu normalitas, linieritas dan hipotesis.

\section{HASIL PENELITIAN}

Pada bagian deskripsi data ini berisikan gambaran yang rinci tentang korelasi motivasi belajar (X1) dan disiplin belajar (X2) dengan hasil belajar Simulasi dan Komunikasi Digital (Variabel Y). Data diperoleh dengan menyebarkan angket sebanyak 72 butir item yang terdiri dari 35 butir item untuk variabel $\mathrm{X}_{1}$ (motivasi belajar) 37 butir item untuk variabel $\mathrm{X}_{2}$ (disiplin belajar) dan soal sebanyak 30 butir soal untuk variabel Y (hasil belajar) yang disebarkan kepada 200 responden. Deskripsi data ini dilakukan untuk menggambarkan keadaan masing-masing variabel yang mencakup jumlah nilai, mean, median, modus, nilai minimum, nilai maksimum, range, interval, panjang kelas, varians dan standar deviasi.

Data variabel motivasi belajar dikumpulkan melalui angket yang terdiri dari 35 butir pernyataan yang telah diuji validitas dan reliabilitasnya. Selanjutnya angket diberikan kepada 200 orang responden untuk diisi. Dari data penelitian diketahui bahwa distribusi skor jawaban menyebar terendah 100 dan tertinggi 175 . Berdasarkan distribusi skor tersebut didapat rata-rata (mean) sebesar 140,825 skor tengah (median) 144, skor yang banyak muncul (mode) 140, varians 347,937 dan simpangan baku (standar deviasi) 18,653. Berikut merupakan gambaran yang jelas tentang distribusi skor tentang motivasi belajar, dapat dilihat pada tabel 2 .

Tabel 2. Distribusi Frekuensi Variabel Motivasi Belajar

\begin{tabular}{lllll}
\hline \multirow{2}{*}{ No } & \multicolumn{2}{l}{ Variabel $\mathbf{X}_{\mathbf{1}}$} & & \\
\cline { 2 - 5 } & $\begin{array}{l}\text { Interval } \\
\text { Skor }\end{array}$ & $\begin{array}{l}\text { Frekuensi } \\
\text { Mutlak }\end{array}$ & $\begin{array}{l}\text { Frekuensi } \\
\text { Relatif (\%) }\end{array}$ & $\begin{array}{l}\text { Frekuensi } \\
\text { Kumulatif (\%) }\end{array}$ \\
\hline 1 & $100-108$ & 4 & 2,0 & 2,0 \\
\hline 2 & $109-117$ & 20 & 10,0 & 12,0 \\
\hline 3 & $118-126$ & 29 & 14,5 & 26,5 \\
\hline 4 & $127-135$ & 34 & 17,0 & 43,5 \\
\hline 5 & $136-144$ & 20 & 10,0 & 53,5 \\
\hline
\end{tabular}

\section{Paris Langkis}

Vol.2 Nomor 1, Agustus 2021 


\begin{tabular}{lllll}
\hline 6 & $145-153$ & 36 & 18,0 & 71,5 \\
\hline 7 & $154-162$ & 27 & 13,5 & 85,0 \\
\hline 8 & $163-171$ & 21 & 10,5 & 95,5 \\
\hline 9 & $172-180$ & 9 & 4,5 & 100,0 \\
\hline Jumlah & 200 & 100 & \\
\hline
\end{tabular}

Data variabel disiplin belajar dikumpulkan melalui butir pernyataan angket yang terdiri dari 37 butir pernyataan yang telah diuji validitas dan reliabilitasnya. Selanjutnya angket diberikan kepada 200 orang responden untuk diisi. Dari data penelitian diketahui bahwa distribusi skor terendah 106 dan tertinggi 185. Berdasarkan distribusi skor tersebut didapat rata-rata (mean) sebesar 147,335, skor tengah (median) 147, skor yang banyak muncul (mode) 145, varians sebesar 353,390 dan simpangan baku (standar deviasi) 18,798. Berikut merupakan gambaran yang jelas tentang distribusi skor disiplin belajar, dapat dilihat pada tabel 3.

Tabel 3. Distribusi Frekuensi Variabel Disiplin Belajar

\begin{tabular}{|c|c|c|c|c|}
\hline \multirow[b]{2}{*}{ No } & \multicolumn{4}{|c|}{ Variabel $X_{2}$} \\
\hline & $\begin{array}{l}\text { Interval } \\
\text { Skor }\end{array}$ & $\begin{array}{l}\text { Frekuensi } \\
\text { Mutlak }\end{array}$ & $\begin{array}{l}\text { Frekuensi } \\
\text { Relatif (\%) }\end{array}$ & $\begin{array}{l}\text { Frekuensi } \\
\text { Kumulatif (\%) }\end{array}$ \\
\hline 1 & $106-114$ & 9 & 4,5 & 4,5 \\
\hline 2 & $115-123$ & 9 & 4,5 & 9,0 \\
\hline 3 & $124-132$ & 26 & 13,0 & 22,0 \\
\hline 4 & 133-141 & 37 & 18,5 & 40,5 \\
\hline 5 & $142-150$ & 42 & 21,0 & 61,5 \\
\hline 6 & $151-159$ & 18 & 9,0 & 70,5 \\
\hline 7 & $160-168$ & 28 & 14,0 & 84,5 \\
\hline 8 & $169-177$ & 20 & 10,0 & 94,5 \\
\hline 9 & $178-186$ & 11 & 5,5 & 100,0 \\
\hline \multicolumn{2}{|c|}{ Jumlah } & 200 & 100 & \\
\hline
\end{tabular}

Data variabel hasil belajar Simulasi dan Komunikasi Digital dikumpulkan melalui butir soal yang terdiri dari 30 butir soal yang telah diuji validitas, reliabilitas, indeks kesukaran dan daya pembeda. Selanjutnya soal diberikan kepada 200 orang responden untuk diisi. Dari data penelitian diketahui bahwa distribusi skor terendah 77 dan tertinggi 100. Berdasarkan distribusi skor tersebut didapat rata-rata (mean) sebesar 89,274 skor tengah (median) 91, skor yang banyak muncul (mode) 90, varians sebesar 37,912 dan simpangan baku (standar deviasi) 6,157. Berikut ini gambarannya pada tabel 4 .

Tabel 4. Distribusi Frekuensi Variabel Hasil Belajar

\begin{tabular}{lllll}
\hline \multirow{2}{*}{ No } & \multicolumn{2}{l}{ Variabel Y } & & \\
\cline { 2 - 5 } & $\begin{array}{l}\text { Interval } \\
\text { Skor }\end{array}$ & $\begin{array}{l}\text { Frekuensi } \\
\text { Mutlak }\end{array}$ & $\begin{array}{l}\text { Frekuensi } \\
\text { Relatif (\%) }\end{array}$ & $\begin{array}{l}\text { Frekuensi } \\
\text { Kumulatif (\%) }\end{array}$ \\
\hline 1 & $74-76$ & 0 & 0,0 & 0,0 \\
\hline 2 & $77-79$ & 11 & 5,5 & 5,5 \\
\hline
\end{tabular}




\begin{tabular}{lllll}
\hline 3 & $80-82$ & 14 & 7,0 & 12,5 \\
\hline 4 & $83-85$ & 25 & 12,5 & 25,0 \\
\hline 5 & $86-88$ & 32 & 16,0 & 41,0 \\
\hline 6 & $89-91$ & 45 & 22,5 & 63,5 \\
\hline 7 & $92-94$ & 33 & 16,5 & 80,0 \\
\hline 8 & $95-97$ & 28 & 14,0 & 94,0 \\
\hline 9 & $98-100$ & 12 & 6,0 & 100,0 \\
\hline \multicolumn{7}{l}{ Jumlah } & 200 & 100 & \\
\hline
\end{tabular}

Sebelum melaksanakan uji hipotesis, terlebih dahulu dilaksanakan uji prasyarat analisis, yaitu uji normalitas dan uji linieritas. Uji normalitas digunakan untuk mengetahui apakah populasi data berdistribusi normal atau tidak. Uji normalitas dilakukan dengan menggunakan rumus Liliefors yang dihitung secara manual. Hasil uji normalitas dapat dilihat pada tabel 5 berikut:

Tabel 5. Uji Normalitas

\begin{tabular}{lllllll}
\hline No & Kelas & $\mathbf{N}$ & $\mathbf{L}_{0}$ & $\mathrm{~L}_{\mathbf{t}}$ & Perbandingan & Ket \\
$\dot{\text { 1. }}$ & $\mathrm{X}_{1}$ & 200 & $-0,0035$ & 0,0626 & $\mathrm{~L}_{\text {hitung }}<\mathrm{L}_{\text {tabel }}$ & Normal \\
\hline 2. & $\mathrm{X}_{2}$ & 200 & $-0,0032$ & 0,0626 & $\mathrm{~L}_{\text {hitung }}<\mathrm{L}_{\text {tabel }}$ & Normal \\
\hline 3. & $\mathrm{Y}$ & 200 & 0,0118 & 0,0626 & $\mathrm{~L}_{\text {hitung }}<\mathrm{L}_{\text {tabel }}$ & Normal \\
\hline
\end{tabular}

Berdasarkan tabel 16 diperoleh $\mathrm{L}_{0}$ untuk variabel $\mathrm{X}_{1}$ (motivasi belajar) sebesar 0,0035, untuk variabel $X_{2}$ (disiplin belajar) sebesar $-0,0032$ dan $L_{0}$ untuk variabel $Y$ (hasil belajar) sebesar 0,0118 . Sedangkan nilai $\mathrm{L}_{\mathrm{t}}$ adalah 0,0626 yang diperoleh dari nilai kritis $\mathrm{L}$ untuk uji Liliefors. Karena hasilnya Lhitung<Ltabel maka sampel dikatakan berdistribusi normal. Perhitungan dapat dilihat pada lampiran 14, maka prasyarat uji hipotesis selanjutnya dapat dilakukan.

Uji linieritas bertujuan untuk mengetahui apakah variabel motivasi belajar $\left(\mathrm{X}_{1}\right)$ dan disiplin belajar $\left(\mathrm{X}_{2}\right)$ mempunyai korelasi yang linear atau tidak secara signifikan terhadap variabel hasil belajar (Y). Uji linieritas biasanya digunakan sebagai persyaratan dalam analisis korelasi atau regresi linear. Dapat dikatakan hubungan linear secara signifikansi antar variabel bila signifikansi lebih besar dari alpha (0.05). Hasil uji linearitas data dapat dilihat pada tabel 6 berikut.

Tabel 6. Hasil Uji Linearitas Data

\begin{tabular}{lcccc}
\hline Variabel & Sig. & Fhitung & Ftable & Kriteria \\
\hline $\mathrm{X}_{1}-\mathrm{X}_{2}-\mathrm{Y}$ & 0,05 & 10,913 & 1,264 & Linear \\
\hline
\end{tabular}

Berdasarkan tabel hasil uji linieritas di atas diperoleh nilai $F_{\text {hitung }}=10,913$ sedangkan $\mathrm{F}_{\text {tabel }}=1,264$ yang diperoleh dari distribution table Nilai $\mathrm{F}$ pada signifikansi 0,05. Karena nilai $\mathrm{F}_{\text {hitung }}$ lebih besar dari $\mathrm{F}_{\text {tabel }}$ maka dapat disimpulkan bahwa terdapat hubungan linear secara signifikan antara variabel motivasi belajar $\left(\mathrm{X}_{1}\right)$ dan disiplin belajar $\left(\mathrm{X}_{2}\right)$ dengan hasil belajar (Y). Maka dengan demikian uji hipotesis dapat dilaksanakan. Pengujian hipotesis ini dilakukan secara manual. 
Uji korelasi sederhana dilakukan untuk menyatakan berapa besar hubungan antara satu variabel bebas dan satu variabel terikat. Uji hipotesis bertujuan untuk menguji apakah hipotesis yang diajukan diterima atau ditolak. Rumus yang digunakan dalam pengujian ini adalah rumus korelasi Product Moment oleh (Anas Sudijono, 2011). Uji korelasi sederhana dilakukan dengan menggunakan rumus uji korelasi Product Moment, dari hasil pengujian korelasi Product Moment didapatkan nilai $\mathrm{r}_{\text {hitung }}$ kemudian dibandingkan dengan $\mathrm{r}_{\text {tabel }}$. Berdasarkan hasil perhitungan uji $\mathrm{r}$ dapat dilihat pada tabel 7 diperoleh :

Tabel 7.Rangkuman Uji Korelasi Sederhana

\begin{tabular}{llll}
\hline Hipotesis & $\mathbf{r}_{\text {hitung }}$ & $\mathbf{R}_{\text {tabel }}(5 \%)$ & Ket \\
\hline $\mathrm{X}_{1} \mathrm{Y}$ & 0,8097 & 0,138 & Hipotesis pertama diterima \\
\hline $\mathrm{X}_{2}-\mathrm{Y}$ & 0,3658 & 0,138 & Hipotesis kedua diterima \\
\hline $\mathrm{X}_{1} \mathrm{X}_{2}-\mathrm{Y}$ & 0,2744 & 0,138 & Hipotesis Ketiga diterima \\
\hline
\end{tabular}

Berdasarkan tabel 7 didapatkan hasil bahwa $r_{\text {hitung }}>r_{\text {tabel, }}$, sehingga dapat disimpulkan bahwa hipotesis pertama, kedua dan ketiga diterima. Jadi adanya kontribusi yang positif dan signifikan antara motivasi belajar dan hasil belajar $\left(\mathrm{X}_{1}-\mathrm{Y}\right)$, disiplin belajar dengan hasil belajar $\left(\mathrm{X}_{2}-\mathrm{Y}\right)$, kemudian antara motivasi belajar dan disiplin belajar secara bersama dengan hasil belajar $\left(\mathrm{X}_{1} \mathrm{X}_{2}-\mathrm{Y}\right)$.

\section{Tabel 8. Rangkuman Uji t}

\begin{tabular}{llll}
\hline Hipotesis & $\mathbf{t}_{\text {hitung }}$ & $\mathbf{t}_{\text {tabel }}(\mathbf{5 \%})$ & Ket \\
\hline $\mathrm{rx}_{1} \mathrm{y}$ & 19,419 & 1,972 & Hipotesis pertama diterima \\
\hline $\mathrm{rx}_{2} \mathrm{y}$ & 5,5310 & 1,972 & Hipotesis kedua diterima \\
\hline
\end{tabular}

Berdasarkan tabel 19 dapat dikatakan $t_{\text {hitung }}>t_{\text {tabel }}$ maka hipotesis pertama dan kedua diterima. Jadi dapat ditarik kesimpulan adanya korelasi yang positif dan signifikan antara motivasi belajar dengan hasil belajar $\left(\mathrm{X}_{1}-\mathrm{Y}\right)$ dan disiplin belajar dengan hasil belajar $\left(\mathrm{X}_{2}-\mathrm{Y}\right)$ Simulasi Digital siswa kelas X di SMKN 6 Padang.

Selanjutnya dilaksanakan uji korelasi ganda. Uji korelasi ganda dilakukan untuk menyatakan berapa besar hubungan antara dua variabel bebas atau lebih dan satu variabel terikat. Sebelum mencari nilai F, terlebih dahulu dicari nilai korelasi product moment antara ketiga variabel tersebut yaitu $\mathrm{Rx}_{1} \mathrm{x}_{2} \mathrm{y}$. Berikut ini hasil uji korelasi bergandanya, yaitu:

Tabel 9. Rangkuman Uji Korelasi Ganda

\begin{tabular}{|l|l|l|l|}
\hline Hipotesis & $\mathbf{r}_{\text {hitung }}$ & $\mathbf{r}_{\text {tabel }}(5 \%)$ & Ket \\
\hline $\mathrm{Rx}_{1} \mathrm{x}_{2} \mathrm{y}$ & 0,2744 & 0,138 & Hipotesis ketiga diterima \\
\hline
\end{tabular}


Hasil uji korelasi ganda dapat dilihat berdasarkan lampiran 16. Setelah dicari korelasi berganda menggunakan korelasi product moment dilanjutkan dengan uji $\mathrm{F}$, dari hasil pengujian $\mathrm{F}$ didapatkan nilai $\mathrm{F}_{\text {hitung }}$ kemudian dibandingkan dengan $\mathrm{F}_{\text {tabel }}$. Berdasarkan hasil perhitungan uji $\mathrm{F}$ dapat dilihat pada tabel 10, yaitu:

Tabel 10. Rangkuman Uji F

\begin{tabular}{|l|l|l|l|}
\hline Hipotesis & $\mathrm{F}_{\text {hitung }}$ & $\mathrm{F}_{\text {tabel }}(\mathbf{5 \% )}$ & Ket \\
\hline $\mathrm{X}_{1} \mathrm{X}_{2} \mathrm{Y}$ & 18,8 & 1,264 & Hipotesis ketiga diterima \\
\hline
\end{tabular}

Berdasarkan tabel 10 didapatkan hasil bahwa $F_{\text {hitung }}>F_{\text {tabel, }}$ sehingga dapat disimpulkan bahwa hipotesis ketiga. Jadi adanya korelasi yang positif dan signifikan antara motivasi belajar $\left(\mathrm{X}_{1}\right)$ dan disiplin belajar $\left(\mathrm{X}_{2}\right)$ dengan hasil belajar Simulasi dan Komunikasi Digital (Y). Selanjutnya dilaksanakan pencarian koefisien determinasi. Penentuan seberapa besar pengaruh antara variabel independen terhadap variabel dependen yang ditunjukan oleh besarnya koefisien determinasi. Berdasarkan output nilai $r^{2}$ pada lampiran 16 menunjukan angka sebesar 7,52\% artinya persentase sumbangan motivasi belajar (Variabel $\mathrm{X}_{1}$ ) dan disiplin belajar $\left(\mathrm{X}_{2}\right)$ dengan hasil belajar (Variabel $\mathrm{Y}$ ) sebesar 7,52\%. Sehingga dapat disimpulkan bahwa terdapat 7,52\% kontribusi diberikan variabel $\mathrm{X}_{1}$ dan $\mathrm{X}_{2}$ terhadap variabel $\mathrm{Y}$, sedangkan 92,48\% lainnya dipengaruhi oleh faktor lain di luar yang diteliti.

Hasil analisis penelitian ini berisi tentang deskripsi data motivasi belajar dan disiplin belajar dengan hasil belajar Simulasi dan Komunikasi Digital. Motivasi belajar( $\left.\mathrm{X}_{1}\right)$ merupakan keseluruhan daya penggerak dalam diri siswa yang menimbulkan kegiatan belajar, yang menjamin kelangsungan dari kegiatan belajar dan memberikan arah pada kegiatan belajar, sehingga tujuan yang dikehendaki oleh subyek belajar itu dapat tercapai (Sardiman, 2006). Selanjutnya menurut Uno (2006) motivasi belajar dapat timbul karena faktor intrinsik, berupa hasrat dan keinginan berhasil dan dorongan kebutuhan belajar, harapan akan cita-cita. Sedangkan faktor ekstrinsiknya adalah adanya penghargaan, lingkungan belajar yang kondusif, dan kegiatan belajar yang menarik.

Sedangkan disiplin belajar $\left(\mathrm{X}_{2}\right)$ adalah kemampuan untuk mengendalikan diri dalam bentuk tidak melakukan suatu tindakan yang tidak sesuai dan bertentangan dengan sesuatu yang telah ditetapkan dan melakukan sesuatu yang mendukung dan melindungi sesuatu yang telah ditetapkan Berdasarkan pengertian ini, berarti seseorang yang disiplin akan berusaha untguk mengendalikan dirinya agar dapat melakukan sesuatu yang tidak bertentangan dengan peraturan yang ada serta senantiasa mendukung peraturan tersebut. Selanjutnya hasil belajar adalah angka yang diperoleh siswa yang telah berhasil menuntaskan konsep-konsep mata pelajaran sesuai dengan kriteria ketuntasan minimal (KKM) yang ditetapkan sesuai dengan kurikulum yang berlaku.

Berdasarkan penelitian ini diketahui kontribusi motivasi belajar $\left(\mathrm{X}_{1}\right)$ dan disiplin belajar $\left(\mathrm{X}_{2}\right)$ dengan hasil belajar Simulasi dan Komunikasi Digital $(\mathrm{Y})$ siswa kelas X di SMKN 6 Padang adalah sebesar 7,52\%. Hasil analisis data dan pengujian hipotesis menunjukan bahwa hipotesis yang diuji dalam penelitian ini diterima. Dengan demikian maka variabel $\mathrm{X}_{1}$ (motivasi belajar) dan $\mathrm{X}_{2}$ (disiplin belajar) memiliki kontribusi yang positif dan signifikan terhadap variabel $Y$ (hasil belajar). 
Pengujian hipotesis ini menggunakan korelasi ganda yang bertujuan untuk mengetahui korelasi yang terjadi antara motivasi belajar dan disiplin belajar dengan hasil belajar Simulasi dan Komunikasi Digital. Hasil uji korelasi yang diperoleh untuk variabel $\mathrm{X}_{1}$ (motivasi belajar) dengan variabel Y (hasil belajar) adalah 0,8097, korelasi antara variabel $\mathrm{X}_{2}$ (disiplin belajar) dengan variabel Y (hasil belajar) adalah 0,3658 , sedangkan untuk dengan Rtabel sebesar 0,138. Karena $\mathrm{r}_{\text {hitung }>\text { rtabel }}$ maka dapat ditarik kesimpulan bahwa korelasi dikatakan positif dan signifikan dan dapat dilanjutkan dengan uji signifikan. Uji signifikan dicari dengan menggunakan uji t. Sehingga diperoleh hasil $t_{\text {hitung }}=19,419$ sedangkan $t_{\text {tabel }}=1,972\left(t_{\text {hitung }} t_{\text {tabel }}\right)$ untuk variabel $X_{1}$ (motivasi belajar) dan $Y$ (hasil belajar). Sedangkan hasil uji signifikan variabel $\mathrm{X}_{2}$ (disiplin belajar) dan $\mathrm{Y}$ (hasil belajar) adalah 5,5310 dengant $_{\text {tabel }}=1,972\left(t_{\text {hitung }}>t_{\text {tabel }}\right)$. Maka dapat ditarik kesimpulan bahwa hipotesis ketiga diterima.

Pada penelitian ini motivasi belajar (Variabel $\mathrm{X}_{1}$ ) dan disiplin belajar $\left(\mathrm{X}_{2}\right)$ memberikan kontribusi yang cukup terhadap hasil belajar Simulasi dan Komunikasi Digital siswa kelas X di SMKN 6 Padang yaitu sebesar 7,52\%. Sebagaimana dapat dijelaskan melalui nilai $F_{\text {hitung }}$ pada penelitian ini yaitu 18,8 dengan $F_{\text {tabel }} 1,264$ diketahui bahwa variabel $\mathrm{X}_{1}$ (motivasi belajar) dan variabel $\mathrm{X}_{2}$ (disiplin belajar) memiliki korelasi yang positif dan signifikan terhadap variabel Y (hasil belajar). Maka dapat disimpulkan bahwa hipotesis pertama, kedua dan ketiga diterima.

\section{E. KESIMPULAN}

Berdasarkan hasil analisis penelitian tentang korelasi motivasi belajar (X1) dan disiplin belajar (X2) dengan hasil belajar Simulasi dan Komunikasi Digital (Y) siswa kelas X di SMKN 6 Padang, maka dapat ditarik kesimpulan yaitu:

1. Terdapat korelasi yang positif dan signifikan motivasi belajar dengan hasil belajar Simulasi dan Komunikasi Digital siswa.

2. Terdapat korelasi yang positif dan signifikan disiplin belajar belajar dengan hasil belajar Simulasi dan Komunikasi Digital siswa.

3. Terdapat korelasi yang positif dan signifikan motivasi belajar dan disiplin belajar secara bersama-sama dengan hasil belajar Simulasi dan Komunikasi Digital siswa.

Berdasarkan perhitungan uji korelasi berganda menunjukkkan bahwa hasilnya adalah $\mathrm{r}_{\text {hitung }>\text { rtabel }}(0,2744>0,138)$. Sehingga dapat ditarik kesimpulan bahwa korelasi dikatakan positif, dan dapat dilanjukan dengan uji signifikan. Uji signifikan dicari dengan menggunakan uji $F$, sehingga diperoleh hasil dengan $F_{\text {hitung }}=18,8$ sedangkan $F_{\text {tabel }}=1,264$ $\left(F_{\text {hitung }}>\mathrm{f}_{\text {tabel }}\right)$. Nilai tersebut memberikan kesimpulan bahwa terdapat korelasi yang positif dan signifikan motivasi belajar dan disiplin belajar secara bersama-sama terhadap hasil belajar Simulasi dan Komunikasi Digital siswa kelas X di SMKN 6 Padang Tahun Pelajaran 2019/2020. Berdasarkan penjelasan di atas dapat ditarik kesimpulan bahwa hipotesis ketiga dalam penelitian ini diterima.

\section{REFERENSI}

Affifudin. (2008). Motivasi Pembelajaran. Jakarta: Balai Pustaka. Ahmadi, A. (2010). Hasil Belajar Siswa. Jakarta: Rineka Cipta. 
Asmara. (2009 ). Evaluasi Hasil Belajar. Jakarta: Rineka Cipta.

Bima, S. (2016). Korelasi Persepsi Siswa Mengenai Keterampilan Guru dalam Mengajar dan Disiplin Belajar Terhadap Hasil Belajar Matematika di SMA 1 Bandung. Bandung: UPI.

Djamarah. (2008). Interaksi Motivasi Belajar Mengajar. Jakarta: Balai Pustaka.

Engkoswara. (2010). Kiat Sukses Membangkitkan Motivasi Belajar Peserta Didik. Jakarta: Djambatan.

Hamalik. (2008). Penilaian Hasil Belajar. Jakarta: Pustaka Zahra.

Hamdani. (2006). Hasil Pembelajaran di Sekolah. Jakarta: Rineka Cipta.

Irianto, A. (1988). Bahan Ajaran Statistika Pendidikan (Buku Kedua). Padang: UNP Press.

JUWITA, A. I. (2019). Penelitian Hubungan Gaya Belajar dengan Hasil Belajar pada Mata Pelajaran Simulasi dan Komunikasi Digital.

JUWITA, A. I. (2019). Penelitian Hubungan Gaya Belajar dengan Hasil Belajar pada Mata Pelajaran Simulasi dan Komunikasi Digital. JURNAL PTI (PENDIDIKAN DAN TEKNOLOGI INFORMASI) FAKULTAS KEGURUAN ILMU PENDIDIKAN UNIVERSITA PUTRA INDONESIA.

Mahendra. (2008). Bagaimana Meningkatkan Disiplin Belajar Siswa. Bandung: Alfabeta.

Menrisal. (2018). HUBUNGAN PERSEPSI SISWA TENTANG KOMPETENSI PEDAGOGIK DAN KOMPETENSI SOSIAL GURU PLK TERHADAP MINAT BELAJAR SISWA.

Moenir. ( 1995). Disiplin Kelima. Jakarta Selatan: Gaya Favorit Press.

Mudijono, D. \&. (2006). Hakikat Hasil Belajar. Jakarta: Pustaka Zahra.

Mujiono. ( 2006). Kiat Menumbuhkan Disiplin Belajar Anak. Bandung: Alfabeta.

Mukhlis, H. (2016). Kontribusi Persepsi Siswa Tentang Keterampilan Mengajar Guru dan Disiplin Belajar Terhadap Hasil Belajar Bahasa Indonesia di SMA Negeri 1 Solo. Jakarta: UNJ.

Popi Radyuli, Darma Sanjaya, Zakia Zuzanti. (2020). KONTRIBUSI LINGKUNGAN BELAJAR DAN SARANA PRASARANA TERHADAP HASIL BELAJAR SISWA MATA PELAJARAN TIK (Studi Kasus Kelas XI IPS SMA PGRI 1 Padang). 1(1).

Sudijono, A. (2011). Evaluasi Pendidikan. Jakarta: Rajawali Press.

Wallen, F. \&. (2008). How to Design and Evaluate Research in Education. New York: McGraw-Hill Higher Education.

Wijaya, C. (2001). Peran Disiplin Pada Perilaku Siswa. Jakarta: Djambatan. 